\title{
Caught in-between: System for in-flow inactivation of enzymes as an intermediary step in "plug-and-play" microfluidic platforms
}

\author{
Fernandes, Ana C.; Petersen, Benjamin; Møller, Lars; Gernaey, Krist V.; Krühne, Ulrich
}

Published in:

New Biotechnology

Link to article, DOI:

10.1016/j.nbt.2018.04.002

Publication date:

2018

Document Version

Peer reviewed version

Link back to DTU Orbit

Citation (APA):

Fernandes, A. C., Petersen, B., Møller, L., Gernaey, K. V., \& Krühne, U. (2018). Caught in-between: System for in-flow inactivation of enzymes as an intermediary step in "plug-and-play" microfluidic platforms. New

Biotechnology, 47, 39-49. https://doi.org/10.1016/j.nbt.2018.04.002

\section{General rights}

Copyright and moral rights for the publications made accessible in the public portal are retained by the authors and/or other copyright owners and it is a condition of accessing publications that users recognise and abide by the legal requirements associated with these rights.

- Users may download and print one copy of any publication from the public portal for the purpose of private study or research.

- You may not further distribute the material or use it for any profit-making activity or commercial gain

- You may freely distribute the URL identifying the publication in the public portal 


\section{Accepted Manuscript}

Title: Caught in-between: System for in-flow inactivation of enzymes as an intermediary step in "plug-and-play" microfluidic platforms

Authors: Ana C. Fernandes, Benjamin Petersen, Lars Møller, Krist V. Gernaey, Ulrich Krühne

PII:

DOI:

Reference:

S1871-6784(17)30331-X https://doi.org/10.1016/j.nbt.2018.04.002

NBT 1076

To appear in:

Received date: $\quad$ 23-7-2017

Revised date: $\quad 15-4-2018$

Accepted date: $\quad$ 16-4-2018

Please cite this article as: Fernandes, Ana C., Petersen, Benjamin, Møller, Lars, Gernaey, Krist V., Krühne, Ulrich, Caught in-between: System for in-flow inactivation of enzymes as an intermediary step in "plug-and-play" microfluidic platforms.New Biotechnology https://doi.org/10.1016/j.nbt.2018.04.002

This is a PDF file of an unedited manuscript that has been accepted for publication. As a service to our customers we are providing this early version of the manuscript. The manuscript will undergo copyediting, typesetting, and review of the resulting proof before it is published in its final form. Please note that during the production process errors may be discovered which could affect the content, and all legal disclaimers that apply to the journal pertain. 


\title{
Caught in-between: System for in-flow inactivation of enzymes as an intermediary step in "plug-and-play" microfluidic platforms
}

\author{
Ana C. Fernandes ${ }^{*}$, Benjamin Petersen ${ }^{2}$, Lars Møller ${ }^{2}$, Krist V. Gernaey ${ }^{1}$ and Ulrich Krühne ${ }^{1}$ \\ ${ }^{1}$ Process and Systems Engineering Center (PROSYS), Department of Chemical and Biochemical \\ Engineering, Technical University of Denmark, Building 229, 2800 Kgs. Lyngby, Denmark \\ ${ }^{2}$ Kemiteknik Workshop, Department of Chemical and Biochemical Engineering, Technical \\ University of Denmark, Building 229, 2800 Kgs. Lyngby, Denmark
}

*Correspondence: ancafe@kt.dtu.dk

\section{Highlights}

- A simple method for fast ( $20 \mathrm{~s})$ inactivation of biocatalysts under flow conditions.

- A microfluidic device capable of accommodating a wide range of inactivation temperatures.

- A microfluidic system capable of integration in a modular platform.

- Characterization of the microfluidic device using computational fluid dynamics.

\section{Abstract}

The need for fast and comprehensive characterization of biocatalysts has pushed the development of new screening platforms based on microfluidics, capable of monitoring several parameters simultaneously, with new configurations of liquid handling, sample treatment and sensing. Modular microfluidics allows the integration of these newly developed approaches in a more flexible way towards increasing applicability of the microfluidic chips to different types of biocatalysts and reactions. A highly relevant operation in such a system is biocatalyst inactivation, which can enable the precise control of reaction time by avoiding the continuation of the reaction in another module or connecting tubes. Such control is important when different modules of reactors and/ or sensing units are used and changed frequently. Here we describe the development, characterization and application of a module for rapid enzyme inactivation. The thermal inactivation platform developed is compared with a standard benchtop ThermoMixer in terms of inactivation efficiency for glucose oxidase and catalase. A higher activity loss was observed for enzyme inactivation under flow conditions (inactivation achieved at $120 \mathrm{~s}$ residence time at $338 \mathrm{~K}$ and $20 \mathrm{~s}$ residence time at $353 \mathrm{~K}$ ) 
which indicated a high heat transfer to the fluid under dynamic conditions. Moreover, partial deactivation of the enzymes was observed for the continuous thermal inactivation module, when activity measurements were performed after 1 and 2 days following inactivation. The thermal inactivation unit presented can be easily integrated into modular microfluidic platforms and can be a useful addition for enzyme characterization and screening.

\section{List of Abbreviations}

$\begin{array}{ll}\text { TEM } & \text { Thermoelectric modules or peltier elements } \\ \text { MW } & \text { Microwave } \\ \text { IR } & \text { Infrared } \\ \text { RF } & \text { Radiofrequency } \\ \text { MFH } & \text { Magnetic fluid hyperthermia } \\ \text { PCR } & \text { Polymerase chain reaction } \\ \text { DCHBS } & \text { Sodium 3,5-dichloro-2-hydroxy-benzenesulfonate } \\ \text { 4-AAP } & \text { 4-aminoantipyrine } \\ \text { PP } & \text { Polypropylene } \\ \text { PTFE } & \text { Polytetrafluoroethylene } \\ \text { GOx } & \text { Glucose oxidase } \\ \text { Cat } & \text { Catalase } \\ \text { d } & \text { Day(s) } \\ \text { HPLC } & \text { High throughput liquid chromatographer } \\ \text { ThermoMixer } & \text { MRH11 Heating ThermoMixer } \\ \text { CFD } & \text { Computational fluid dynamics } \\ \text { Re } & \text { Reynolds number } \\ \text { FAD } & \text { Flavin adenine dinucleotide }\end{array}$

Keywords: Thermal inactivation, modular platform, microfluidics, continuous operation

\section{Introduction:}

The study of the influence of temperature on biological systems is a standard optimization procedure in current biotechnological processes [1]. As with other operation parameters, temperature is studied in order to obtain the value at which a certain enzyme or organism operates at the maximum rate. An enzyme's temperature operational range is usually a good indicator of its structural robustness and how well it will perform under industrial process conditions. Enzyme temperature persistence or resistance to denaturation, for example, has provided good insight into the structural factors leading to enzymatic increased stability [2], which depends, among other factors, on enzyme mobility and folding mechanisms [3]. Enzymes tend to fold in conformations which are the most thermodynamically stable at the 
prevailing environmental conditions[4]. However, for most enzymes, the native active state is only marginally more stable than the inactive state, due to the higher conformational entropy (conformational freedom) of the latter [4]. Enzyme inactivation can occur through several mechanisms, such as protein aggregation, disruption of the polypeptide chain, dissociation of a prosthetic group from the active site or subunit dissociation [4,5], resulting in loss of conformational structure (denaturation) and functional activity (inactivation). The denaturation process can be caused or initiated through a variety of process conditions (e.g. elevated temperature, extreme $\mathrm{pH}$, high pressure) or solvents (e.g. Guanidinium chloride, urea) [4-7]. Denaturation tends to occur in two steps, where first conformational changes occur that lead to protein denaturation or inactivation, and then the denatured proteins aggregate through non-covalent interactions [1,5-8].

Due to its influence on protein conformation, temperature has been extensively used to inactivate or deactivate enzymes and organisms. Thermal denaturation occurs by the loss of ordered secondary and tertiary structure towards increased entropy due to random and fast cooperative intramolecular movements that occur above a certain temperature (which depends on the environmental conditions) [9]. It has been extensively used to stop reactions (e.g. avoid enzymatic degradation in cells or tissue samples [10]), perform protein conformation studies, inactivate pathogens in infectious samples (through protein denaturation [10]), or to ensure no microbial growth [11] or degradation of food [12]. It is thus highly relevant that platforms for characterization and screening of biocatalysts contain a unit for thermal studies and/or inactivation with good temperature control.

Most research laboratories use conventional convective heating, such as water baths, oil baths or hot plates, as heating or inactivating strategies. However, these methods have several issues. For instance, non-uniform temperature distribution between the heating surface and the bulk of the sample or the time required to reach the set inactivation temperature. Microfluidics can solve these issues, enabling a rapid and more controlled heat transfer to the bulk of the sample, due to the small channel dimensions and available heating strategies alternatives.

Conductive heating at a microscale can be achieved with a variety of strategies, either by integrating heating elements directly within the platform or by using external heating elements. Integrated heating has been achieved through the use of exothermic reactions in parallel microchannels in contact with the main channel [13], but also by on-channel microfabrication of resistors and thin-film resistors [14-17] or metal wires [13]. External heating elements can be hotplates, readily available in most laboratories, but lately thermoelectric modules (TEM) or Peltier elements have gained relevance since they allow a good control of the applied temperatures and are easily connected with existing electronic components. Peltier elements are now relatively ubiquitous in benchtop analytical equipment for temperature control [18], but are also increasingly used in microfluidic applications $[13,19]$, being employed in applications that require a high degree of temperature control with fast switching between temperatures [19,20]. 
Other (non-contact) heating strategies have also been applied at a microscale, some of them used in industrial applications. Microwave (MW) dielectric heating enabled higher thermocycling rates in PCR applications [13] as well as accelerated reactions [21] compared to integrated heating [13,22,23]. Infrared (IR) heating is another example of an industrially-used heating strategy that has also been applied at the microscale [13,24], with greater emphasis on PCR systems [25]. Radiofrequency (RF) heating for example, which is commonly used on an industrial scale in the food industry, has been used at a microscale to perform magnetic fluid hyperthermia (MFH) on cells [26]. In this technique cells are labelled with magnetic nanoparticles, that increase in temperature when subjected to an alternating current magnetic field (e.g. generated in copper coils integrated in a microchip [26]), thus causing temperature denaturation of the target cells. MFH has also been applied for inactivation of bacteria [27]. A summary of the main thermal characteristics of these systems is presented in Table 1.

Modular platforms, based on the "plug-and-play" approach, enable the connection of independently developed microfluidic units which can be combined or arranged differently, depending on the application, type of sample or reaction [28-33].

In order to obtain a reliable result when performing enzymatic reactions, it is necessary for the samples to be quantified at the same or at a well-defined reaction time point. The quantification of reaction components under flow conditions (as part of a continuous operation platform) requires a comprehensive characterization of the microreactor so that samples obtained at different reaction times can be compared. However, in a modular platform, where the reactor and operation units can be changed, it is essential that samples reach the quantitative system or sensor in the same conditions. Enzymatic reactions can be stopped through addition of reagents that inactivate the enzyme or through compounds that block the active site, but this may interfere with the operation of the sensor used for the quantification (e.g. addition of $\mathrm{NaOH}$ or $\mathrm{HCl}$ for $\mathrm{pH}$ change and enzyme denaturation can destroy the biosensing layer of electrochemical-based sensors).

The microfluidic platform presented was developed as an intermediary step in a modular microfluidic platform and intended to address the latter issue by providing an alternative inactivation strategy: temperature-based enzyme inactivation. Temperature allows an unspecific inactivation of both enzymes and cells, also enabling reversible or irreversible inactivation of the proteins involved depending on the chosen operation conditions, offering a further degree of control on the enzyme state during operation. Temperature is also used in different fields, and so its integration in a modular platform increases the platform's applicability by different users. The platform's inactivation ability was compared with the standard laboratory method in order to validate its usefulness as part of an enzymatic screening platform.

In this work, a new microfluidic platform for thermal inactivation of enzymes was fabricated and its inactivation ability compared with a standard laboratory procedure, a table top orbital heating device. The time required to achieve the desired inactivation temperature was 
simulated in parallel using computational fluid dynamics for further validation of the fabricated platform.

\section{Materials and Methods}

\section{Reagents and Materials}

Glucose oxidase (EC 1.1.3.4, type VII, from Aspergillus niger, $\geq 100,000$ U/g solid), catalase (EC 232-577-1, from bovine liver, lyophilized powder, 2000-5000 units/mg protein), horseradish peroxidase (EC 1.11.1.7, lyophilized, $150 \mathrm{U} / \mathrm{mg}$ ), hydrogen peroxide (Perdrogen ${ }^{\mathrm{TM}}, 30 \%$ (w/w)), sodium 3,5-dichloro-2-hydroxy-benzenesulfonate (DCHBS) and 4 -aminoantipyrine (4-AAP, reagent grade) were from Sigma (St. Louis, MO, USA). D- glucose (anhydrous) was from Fluka (Loughborough, UK). Mono - and di-potassium hydrogen phosphate (anhydrous) were from Merck (Darmstadt, Germany). All the solutions for sensor preparation were prepared with $50 \mathrm{mM}$ phosphate buffer $\mathrm{pH}$ 7.5. All solutions were prepared in buffer.

The 10-mm marlon polycarbonate plate that forms the channel was from Brett Martin (Newtownabbey, UK). The 2-mm thick SS304 stainless steel bottom plate of the channel, as well as the structural components of the platform were from Sanistål (Aalborg, Denmark). The polycarbonate and steel parts were milled using an ecoMill 50 from DMG mori (Bielefeld, Germany). The adhesive assembly of the platform was performed with a $142 \mu \mathrm{m}$ thick doublesided adhesive tape mcs-foil 008 from microfluidic ChipShop (Jena, Germany), previously patterned using laser ablation with a CMA-4030 Laser Engraving machine from GD Han's Yueming Laser Technology co., Ltd (Guangdong, China). Flangeless polypropylene (PP) fingertight $1.5875 \mathrm{~mm}$ (ID) fittings (XP-201) and flangeless ferrules (P200X) from Upchurch Scientific ${ }^{\circledR}$ (Washington, USA) were used to connect polytetrafluoroethylene (PTFE) 1.5875 mm (OD) x 1mm (ID) tubing (S 1810-12) from Bohlender (Grünsfeld, Germany).

\section{Enzyme activity measurements}

Activity measurements of glucose oxidase (GOx) and catalase (Cat) were performed in a UV1800 UV-Vis spectrophotometer with a CPS 240A cell positioner from Shimadzu (Kyoto, Japan). GOx activity was measured using a protocol adapted from Heuts et al. [34], in which $10 \mu \mathrm{L}$ of 1:30 diluted GOx solution $(\sim 30 \mathrm{U} / \mathrm{mL})$ were added to $990 \mu \mathrm{L}$ of the reaction mixture. For the inactivation study, the initial rates of glucose consumption / colorimetric compound formation were compared for a glucose concentration $(400 \mathrm{mM})$ around 10 times the measured $\mathrm{K}_{\mathrm{M}}(\sim 30 \mathrm{mM})$. The activity of Cat $(\sim 400 \mathrm{U} / \mathrm{mL})$ was measured based on the protocols by Beers and Sizer [35] and H. Lück [36], in which $30 \mu \mathrm{L}$ of 1:10 diluted Cat solution was added to $2970 \mu \mathrm{L}$ of $10 \mathrm{mM}$ hydrogen peroxide. Each spectrophotometric measurement was performed in triplicate for $2 \mathrm{~min}$.

\section{Thermal inactivation platform}


The microfluidic thermal inactivation platform has several components, as shown in Figure 1. The microfluidic channel was micromilled in a polycarbonate plate with a meander shape, with $150 \mu \mathrm{m}$ depth and $790 \mu \mathrm{m}$ width, as well as a pocket for a temperature sensor (Figure 2 (a)). The microchannel has two main inlets (forming the primary channel) and two side inlets (forming the secondary channel), which provide a wider range of residence times. The polycarbonate plate was glued onto a thin stainless-steel plate with a patterned double sided adhesive tape, giving the channel an overall height of $292 \mu \mathrm{m}$. A PT 1000 temperature sensor (Platinum Thin Film PTFM102A1A0 from Measurement Specialties (Europe) Ltd., Dortmund, Germany) was placed in contact with the steel plate and connected to a controller (Laird PR-59 Advanced Temperature Controller from Supercool AB, Stromstad, Sweden) which was operated from a personal computer (PC). The controller had an EOS LFWLP3501005 power supply (EOS, Andheri, Mumbai, India). The Peltier elements from Multicomp by Newark element14, Chicago, Illinois, USA have a dimension of $40 \mathrm{mmx} 40 \mathrm{mmx} 3.45 \mathrm{~mm}$, a maximum temperature differential of $70 \mathrm{~K}$ during cooling, and can be controlled with software (SC_Interface) provided with the controller. Before assembly the Peltier elements were covered with a thin layer of a heat transfer paste (HTS Silicone Heat Transfer compound from Electrolube, Leicestershire, UK). To facilitate the cooling of the cool side of the Peltier elements during operation, a heat sink and a fan were connected to the microchannel assembly. The assembled Peltier elements were placed on the heat sink structure, which was milled in order to have the shape of the Peltier elements and enable a good fit of the microchannel assembly onto the heat sink $(60 \mathrm{mmx} 40 \mathrm{mmx} 10 \mathrm{~mm}, 153 \mathrm{AB}$ from ABL Aluminum Components, Birmingham, UK). The fan (614 NGL DC axial fan from Ebm-papst Inc., Farmington, Connecticut, USA) was assembled underneath the heat sink and connected to the controller. The connection of the electronic components was performed in-house, and installed inside a $30 \mathrm{cmx} 30 \mathrm{~cm} \mathrm{x} 10 \mathrm{~mm}$ plastic box. The characterization of the thermal performance of the developed inactivation platform is presented in the supplementary material.

\section{Thermal inactivation measurements}

The study of the enzymatic inactivation ability of the assembled microfluidic platform was performed for each enzyme separately, as presented in Figure 3, by pumping the enzyme solution inside the channel at different flowrates to achieve the desired residence times and temperatures (presented in Table 2). Before introduction of the enzyme solution, the channel was heated to the desired inactivation temperature, and flushed with enzyme solution ( $\operatorname{Re}$ 2.05) for a minimum of 6 times the channel volume before sampling. The enzyme solution was then retrieved at the outlet, appropriately diluted and measured in the spectrophotometer. GOx solutions were also added to a vial with $200 \mathrm{mM}$ glucose solution in a 1:1 proportion, and glucose concentration was measured after 1 and $2 \mathrm{~d}$ in a high-throughput liquid chromatographer (HPLC) Dionex UltiMate 3000 UHPLC system with diode array and refractive index detector (Thermo Fisher Scientific, Waltham, Massachusetts, USA). HPLC data was used to check whether inactivation or denaturation occurred in the platform. In the case of Cat, the same solutions retrieved at the outlet of the microchannel were measured after $1 \mathrm{~d}$ in the UV/VIS spectrophotometer and hydrogen peroxide consumption was compared 
to that of freshly inactivated enzyme. The samples of both enzymes were kept at room temperature following inactivation.

The same study of the enzymatic inactivation ability was performed in a tabletop orbital MRH11 Heating ThermoMixer (HCL BioTech, Bovenden, Germany), for the same temperatures and residence times as for the microfluidic system. In this case, $500 \mu \mathrm{L}$ of the enzyme solution were added to a 4 - $\mathrm{mL}$ vial that was already at the target inactivation temperature. The consumption of glucose by the enzyme solutions inactivated in the ThermoMixer was also measured in the HPLC after $2 \mathrm{~d}$. In both sets of experiments, GOx solutions were freshly prepared, while Cat solutions were diluted from a stock solution ( 1000 $\mathrm{U} / \mathrm{mL}$ ) daily. The activity of Cat in the stock solution was measured daily. The enzymes were kept on ice (around $277 \mathrm{~K}$ ) during the experiments and added to the ThermoMixer and to the channel only when these were heated at the inactivation temperature being tested.

\section{Characterization of thermal inactivation platforms with computational fluid dynamics} (CFD)

The microchannel and 4-mL vial geometries were designed in SolidWorks 2015 (Dassault Systèmes SolidWorks Corporation, Waltham, Massachusetts, USA). The time required to achieve the final inactivation temperature from room temperature (298 K) was simulated using a computational fluid dynamic simulation software, ANSYS-CFX Version 16.2 (Canonsburg, Pennsylvania, USA). The three-dimensional designs of the microchannel (Figure 2 (a)) and 4-mL vial (Figure 4 (a)) were imported into a meshing software, ANSYS ICEM CFD ${ }^{\circledR} 16.0$ (Canonsburg, Pennsylvania, USA), and discretization of the geometry into smaller elements (where the equations for momentum, energy and mass balance [37,38]are solved by ANSYS-CFX software) was performed. The geometry of the 4-mL vial was simplified based on an axial geometry to a slice of $1.24 \%$ of the entire volume, corresponding to the volume of $5^{0}$ of the cylinder vial perimeter (Figure 4 (b)). The slice defined contained 11284 mesh elements (107.5 elements/ $\mu \mathrm{L}$ ). The microchannel geometry was simplified to a straight $30 \mathrm{~cm}$ long channel with one quarter of the width of the actual microchannel and defined with steel underneath and a 5-mm polycarbonate plate on top (Figure 2 (b)) containing 72144 elements (2312.3 elements/ $\mu \mathrm{L})$. Both designs were simulated with a structured hexahedron mesh, assuming that the structures and the environment were at $298 \mathrm{~K}$. In order to simulate the whole structure, symmetry was assumed on both sides of the slice (axial symmetry) and microchannel design. When symmetry is used, the conditions on the areas beyond the simulated volume are a reflection of the simulated conditions. The use of symmetry enables reduction of the computational time required for the simulation [38]. The fluids were simulated according to the Navier-Stokes equation for Newtonian fluids [39] under laminar flow conditions, which was solved coupled with the energy balance [40] using the Thermal Energy model integrated in ANSYS-CFX.

The vial was considered to be made of glass, with a height of $9 \mathrm{~mm}$ corresponding to the liquid and the rest was filled with air. The three phases, solid (glass), liquid (fluid) and gas (air), were defined as separate parts in the geometry with a conservative interface flux condition, 
where only temperature is conducted between the solid and the liquid phase. In both the liquid and the air phases, two fluids were defined: water with a density of $997 \mathrm{Kg} \mathrm{m}^{-3}$ and air with a density of $1225 \mathrm{Kg} \mathrm{m}^{-3}$. In the air phase, air had an initial volume fraction of 1 and water of 0 , while in the liquid phase, the opposite was set. Both fluids were defined as buoyant with $9.81 \mathrm{~m} \mathrm{~s}^{-2}$ as the gravitational acceleration towards the bottom of the vial. The heat was defined as coming only from the glass outer walls (bottom and side of the vial) as presented in Figure 4 (b). The portion of liquid on the bottom was at $277 \mathrm{~K}$ at the start of the simulation, while the air above it was at $298 \mathrm{~K}$.

The microchannel (Figure 2 (b)) was filled with liquid under laminar flow with a flow velocity of $0.025 \mathrm{~m} / \mathrm{s}(\operatorname{Re} 5.60), 0.0025 \mathrm{~m} / \mathrm{s}(\operatorname{Re} 0.56)$ or $0.0018 \mathrm{~m} / \mathrm{s}(\operatorname{Re} 0.40)$, and the heat was defined as coming from the bottom of the channel as in Figure 2 (b). All the materials were simulated considering their properties provided by ANSYS-CFX at $298 \mathrm{~K}$, and the liquid was defined as water. The polycarbonate plate was simulated as polystyrene with a specific heat capacity of $1426 \mathrm{~J} / \mathrm{Kg} \cdot \mathrm{K}$. The walls (top and bottom of the channel) were defined as having no-slip wall boundary conditions, and the outlet was defined as an opening. The simulations were performed as transient in order to obtain the time required for both the liquid and the entire system to reach the target inactivation temperatures.

\section{Results and Discussion:}

The thermal inactivation platform was characterized using two well-known and relatively robust commercially available enzymes, GOx and Cat. Both are relatively stable and present enzymatic activity over a wide range of temperatures (293 K to $333 \mathrm{~K}$ for GOx and $303 \mathrm{~K}$ to $333 \mathrm{~K}$ for Cat), thus providing a good case study to test the efficiency and applicability of the developed inactivation platform.

The platform's performance was compared with a standard laboratory procedure used to achieve thermal enzyme denaturation, a benchtop ThermoMixer. The temperatures and residence times presented in Table 2 were used in both platforms.

In this work, the term enzymatic inactivation will refer to the reversible or irreversible loss of functional activity of proteins. The term enzymatic denaturation will be applied when there is inactivation of an enzyme due to an alteration of its conformation [41]. When there is irreversible loss of enzymatic functional activity, the term enzymatic deactivation will be applied.

\section{Characterization of heating performance with CFD}

A simplified geometry of both systems used to achieve enzymatic thermal denaturation of GOx and Cat was characterized in terms of time required to reach the target temperature using computational fluid dynamics. Three of the target inactivation temperatures, $298 \mathrm{~K}, 318 \mathrm{~K}$ and $353 \mathrm{~K}$, were chosen for comparison of heating performance in the two simulated inactivation systems. 
Figure 5 (a) presents the temperature contour plot of the liquid being heated to $353 \mathrm{~K}$ at the same residence times used in the experiments. Only part of the liquid is first heated to the target temperature $(353 \mathrm{~K})$ after $120 \mathrm{~s}$ of exposure, while uniform heating of the liquid to $353 \mathrm{~K}$ is achieved around $180 \mathrm{~s}$, which corresponds to the longest residence time used for enzyme inactivation in this study. This indicates that the enzyme solutions inactivated in the ThermoMixer were not uniformly exposed to the same temperature for the shorter inactivation times and so higher variability might be expected from these samples, since no mixing was used.

As observed in Figure 5 (a) and (b), for $318 \mathrm{~K}$ and $298 \mathrm{~K}$ respectively, the liquid achieves the target temperature earlier than for $353 \mathrm{~K}$. The target temperatures are achieved between $60 \mathrm{~s}$ and $120 \mathrm{~s}$ after sample heating is initiated for $298 \mathrm{M}$ and $318 \mathrm{~K}$, and thus variability for the corresponding samples at residence times above $120 \mathrm{~s}$ should be very small. Comparing heating times for Figure 5 (a), (b) and (c) the lower the target temperature, the shorter the time required to reach the desired temperature. However, the wider the temperature difference between initial conditions (sample at $277 \mathrm{~K}$ and air at $298 \mathrm{~K}$ ) and inactivation temperature ( $298 \mathrm{~K}, 318 \mathrm{~K}$ and $353 \mathrm{~K}$ ), the faster the heating rate. This is evident in Figure 5 (a) where a temperature of $318 \mathrm{~K}$ is obtained between $30 \mathrm{~s}$ and $60 \mathrm{~s}$, which is consistent with the higher temperature gradient and therewith a higher driving force for the heat transfer to occur in this case $(353 \mathrm{~K})$.

The results from the CFD simulation for the simplified geometry of the microchannel are presented in Figure 6. In this geometry, we considered that the bottom of the microchannel (which corresponds to the steel plate) is at an initial temperature of $353 \mathrm{~K}, 318 \mathrm{~K}$ or $298 \mathrm{~K}$, when the enzyme solution at $277 \mathrm{~K}$ is introduced in the microchannel with a linear velocity of $0.0018 \mathrm{~m} / \mathrm{s}(\operatorname{Re} 0.40)$.

As can be observed for the inactivation temperature of $353 \mathrm{~K}$ (Figure 6 (a)), the liquid flowing inside the channel reaches the desired temperature after $0.6 \mathrm{~s}$. This significantly faster heating of the enzyme solution relative to the 4-mL vial (Figure 5 (a)) is expected, considering the microchannel' s small height $(292 \mu \mathrm{m})$ and reduced volume, which enables a fast heat transfer from the steel plate to all transported fluid. The required time for the fluid to reach the chosen inactivation temperature decreases for lower temperatures, as can be observed in Figure 6 (b) and (c). However, as observed above (Figure 5) for the 4-mL vial, the same temperatures ( $318 \mathrm{~K}$ and $298 \mathrm{~K}$ ) are reached earlier in the $353 \mathrm{~K}$ case (at $0.3 \mathrm{~s}$ the fluid is already between $338 \mathrm{~K}$ and $353 \mathrm{~K}$ ) than for the lower temperatures since the temperature gradient (and thus heat transfer rate) is higher.

It is also relevant to highlight that the inactivation temperature is reached close to the start of the channel, as can be observed in the focused regions in Figure 6 (a) and (b). This means that the enzyme solution is exposed to the desired inactivation temperature through the entire length of the microchannel, and thus that the residence times considered during the experiment are close to the real ones. The distance from the inlet at which the entire volume 
of transported solution reaches the inactivation temperature also decreases with decreasing inactivation temperatures, from $700 \mu \mathrm{m}$ for the simulation at $353 \mathrm{~K}$ to around $550 \mu \mathrm{m}$ at 318 $\mathrm{K}$ and $0 \mu \mathrm{m}$ at $298 \mathrm{~K}$.

To enable the comparison with laboratory enzyme inactivation experiments performed in the microchannel, CFD simulations at $353 \mathrm{~K}$ were performed at different average linear flow velocities between $0.0018 \mathrm{~m} / \mathrm{s}$ and $0.025 \mathrm{~m} / \mathrm{s}$, to include the range of velocities used in the laboratory experiments (see Table 2). No significant difference was observed in the overall temperature distribution or the times at which the set point temperature was reached between the different velocities. However, the distance from the inlet at which the whole liquid reaches $353 \mathrm{~K}$ increases with an increase in flow velocity. This occurs since there is less time due to the fluid's higher velocity for the heat to diffuse across the height of the channel to the solution, as well as some drag of the heat in the direction of the flow (Figure 7). At the lowest simulated velocity this distance is $700 \mu \mathrm{m}$, while at the highest simulated velocity the distance is close to $8 \mathrm{~mm}$. For the maximum experimental velocity $(0.0087 \mathrm{~m} / \mathrm{s})$ this distance is below $3 \mathrm{~mm}$, which is around 1/30 of the length of channel used $(87 \mathrm{~mm})$, and thus its influence in the final used residence time was not considered for the performed experiments. The simulations presented here provide sufficient confidence that the enzyme solution will be uniformly exposed to the inactivation temperature along the entire length of the channel (and close to the assumed residence time).

In all the simulations, after $10 \mathrm{~min}$ the distribution of temperature in the microchannel is approximately the same as the one observed after $1 \mathrm{~h}$, with the temperature at the top of the polycarbonate plate at $298 \mathrm{~K}$. During the experiments however, after approximately 10 to 15 min the top of the polycarbonate plate was hot to the touch. This discrepancy could come from the polycarbonate properties (namely the specific heat capacity) assumed during the simulation, which could differ from those of the polycarbonate used for the microfluidic plate. The temperature during the experiments may also be higher than those simulated. However, since the heat provided by the Peltier elements is regulated based on the temperature measured by the PT 1000 sensor, and this sensor is placed close to the channel, this is not expected to be the case. In the simulations, the area surrounding the channel forming most of the platform, as well as the possible influence of the double adhesive tape between the steel and the polycarbonate plate were not considered. These factors might also affect how heat dissipates from the platform, thus influencing the temperature reached on the outside of the platform.

Nevertheless, since the focus of the CFD simulation was to understand the heat transfer to the enzymatic solution flowing inside the channel, which was possible to visualize in the simulations performed, the simulation was considered to have yielded enough understanding of the heating properties of both inactivation strategies to be able to trust the design of the microfluidic system developed.

\section{Characterization of inactivation performance}


The results from the spectrophotometric measurements performed after the enzyme solutions were sampled from the ThermoMixer or pumped through the microfluidic channel at various residence times and inactivation temperatures are presented in Figure 8, both for GOx and Cat. The presented values have a standard deviation between $3.87^{*} 10^{-9} \mathrm{M} / \mathrm{min}$ and $8.66^{*} 10^{-7}$ $\mathrm{M} / \mathrm{min}$ for GOx and $2.90^{*} 10^{-6} \mathrm{M} / \mathrm{min}$ and $1.29 * 10^{-4} \mathrm{M} / \mathrm{min}$ for Cat.

Both enzymes display a similar inactivation trend. At $338 \mathrm{~K}$ or higher temperatures, a significant decrease in product formation/ hydrogen peroxide consumption is observed in both systems, especially for residence times higher than $60 \mathrm{~s}$. In the ThermoMixer complete inactivation of the enzymes is observed at $353 \mathrm{~K}$ for residence times of 120 and $180 \mathrm{~s}$. This is in agreement with the simulations in Figure 5, where only for these residence times the temperature inside the vial is closer to the desired temperature. In the microchannel, enzyme inactivation occurs at lower temperatures than $353 \mathrm{~K}$. In this system, at $338 \mathrm{~K}$ and residence times of $120 \mathrm{~s}$ and $180 \mathrm{~s}$ almost no activity is observed. This is a good indication that the whole volume of the enzyme solution has been subjected to the same temperature for the defined residence time in the microchannel, as supported by the simulations performed.

Both enzymes seem to behave similarly in terms of inactivation at the temperatures used, although a faster inactivation of Cat was to be expected since it is known to be the less stable of the two enzymes [42]. GOx inactivation is known to occur through loss of its co-factor (FAD), which happens around $332 \mathrm{~K}$, followed by loss of conformation above $335 \mathrm{~K}$ (mid-point for loss of secondary and tertiary structure, according to [43]. This mid-point of conformation loss may even occur at a lower temperature $(328 \mathrm{~K})$ [44]. The values obtained during the experiments agree with the previous temperatures, since the amount of product at $338 \mathrm{~K}$ is around half of the values obtained at $328 \mathrm{~K}$, and a rapid decrease in activity is observed at 338 $\mathrm{K}$. Cat, such as GOx, is prone to denaturation for temperatures above $328 \mathrm{~K}$ [45], due to a process of protein denaturation [46,47]by dissociation of its subunits [42].

The thermal inactivation platform is intended for use as an intermediary step between reaction and quantification, and so should guarantee that the reaction has stopped at the desired residence time before the measurement is performed. Since the measurements performed immediately after inactivation (as would occur in the modular platform) at $353 \mathrm{~K}$ showed no activity for both enzymes, Cat and GOx, this goal seems to have been achieved.

\section{Characterization of deactivation ability}

To check the stability of the inactivation, whether reversible inactivation or deactivation of the enzymes was achieved in the platform, the activity of the inactivated enzyme solutions was measured after one (Cat) and two days (GOx). The substrate concentration measured through HPLC for the different samples obtained is presented in Figure 9 (a). Between measurements, samples were kept at room temperature ( 298 K). As can be observed in Figure 9 (a), samples that flowed inside the microfluidic system consumed less than $10 \mathrm{mM}$ of glucose after 1 and 2 days, while samples inactivated in the ThermoMixer, consumed almost all the glucose present. This may indicate that a partial irreversible denaturation of GOx occurred in the microfluidic platform, while in the ThermoMixer the enzyme was able to return to the active state after 
exposure to the inactivation temperatures and used residence times. For the latter, it was also noticeable that samples inactivated at $298 \mathrm{~K}$ and $310 \mathrm{~K}$ presented a higher overall variability between them, especially at the shorter residence times. This might be related to the observed non-uniform temperature distribution in the simulations performed for the 4-mL vial at the shorter residence times.

In Figure 9 (a), a significant deactivation of GOx was observed for all the inactivation and residence times tested, even for temperatures below FAD dissociation (332 K, according with [43]). Thus, for temperatures below $332 \mathrm{~K}$, GOx deactivation may be caused by other phenomena besides temperature, leading to loss of conformation (e.g. hydrophobic interactions with channel walls). On the other hand, Zoldák et al. [44] observed that irreversible denaturation of GOx occurred if upon inactivation at $328 \mathrm{~K}$ the enzyme solution was immediately cooled to $293 \mathrm{~K}$. They also observed that dissociation of the co-factor and of the protein dimer occurred after the inactivation rate limiting step [44]. This may explain in part the observed deactivation for the temperatures below $328 \mathrm{~K}$, but other phenomena may be involved in the extent of detected denaturation, since no significant difference is observed between the several inactivation temperatures tested in terms of substrate consumption.

The inactivated Cat solutions were kept at room temperature overnight and consumption of hydrogen peroxide was measured in the spectrophotometer the following day (Figure 9 (b)). Samples demonstrated a return of activity for those inactivated at temperatures up to $318 \mathrm{~K}$, and loss or even no activity for samples inactivated at higher temperatures for $180 \mathrm{~s}$. Activity of Cat pumped through the microfluidic system was lower for $338 \mathrm{~K}$ and $353 \mathrm{~K}$ than that inactivated in the ThermoMixer, since some substrate consumption was measured for the latter samples. The occurrence of deactivation in both systems might be related to the previously mentioned lower stability of Cat relative to GOx, thus translating into a smaller difference in deactivation between the two inactivation strategies. Furthermore, Cat solutions from both inactivation systems formed aggregates overnight, especially for the higher residence time (180 s) and inactivation temperatures (338 K and $353 \mathrm{~K}$ ). Protein aggregation indicates loss of conformation due to denaturation, and thus enzymatic deactivation, which is in agreement with the very low substrate consumption measured for these conditions. Cat deactivation associated with protein aggregation is a known phenomenon [48].

Nevertheless, for both enzymes a decrease in enzyme activity was observed with increasing temperature, along with significant difference in substrate consumption between the samples inactivated in the ThermoMixer and in the microfluidic platform. The observed deactivation phenomenon seems to depend on the type of enzyme, since GOx deactivation occurred mainly in the microchannel at all the temperatures used (possibly due to hydrophobic interactions with the channel), while Cat deactivation occured mainly due to the effect of temperature. However, for both enzymes, a high degree of deactivation for the duration of the assay was observed.

The observed partial deactivation for both enzymes in the microfluidic system could be influenced by other factors such as the closer proximity of the transported enzyme to the heat 
source (steel plate forming the bottom of the channel), a more uniform temperature distribution, time controlled exposition to the desired inactivation temperature, and considerably faster heat transfer to the solution $(0.6 \mathrm{~s}$ instead of $178 \mathrm{~s}$ according to the simulations). Furthermore, the platform has a layer of double sided adhesive tape between the steel bottom plate and the channel polycarbonate plate, thus forming part of the walls of the channel. During fluid flow the enzyme may have been exposed to residues of adhesive from this tape, which could further contribute to denaturation. However, since the two enzymes performed differently when pumped inside the system (aggregation in the case of Cat but not GOx, for example), this is probably not a significant factor.

The Peltier elements together with the integrated PT 1000 sensor provide a good control of the applied temperature, enabling a simple setup for thermal inactivation studies. Integration in a modular platform is facilitated by using standard inlet finger tight connectors, but also by designing the meander channel with dimensions compatible with most commercial microfluidic systems. Furthermore, the inclusion of two channels with different lengths increases the flowrates and thus the number of different inactivation times possible for the platform, further increasing its flexibility towards different reactor or sensing modules.

\section{Conclusion:}

The thermal inactivation platform described is capable of achieving rapid inactivation of mesophilic enzymes, such as GOx and Cat. Inactivation is achieved in this system at temperatures around the mid-point of inactivation at relatively long exposure time (120 s at $338 \mathrm{~K})$ or at a higher temperature in a duration compatible with continuous inactivation of enzymes coming from a reactor module (20 s at $353 \mathrm{~K})$. Furthermore, the system causes significant deactivation of both enzymes towards a possibility for storage of the enzymes without the reaction proceeding significantly. The continuous thermal inactivation platform has an improved performance relative to the standard inactivation method at laboratory scale, a benchtop ThermoMixer, since inactivation is achieved faster with the inactivation platform for both enzymes and with a lower residual activity. The characterization of temperature distribution and heating efficiency of both inactivation methods with CFD, also showed a faster heating rate and uniform temperature distribution for the developed microfluidic system. The simulations also demonstrated that the introduced fluid is heated to the inactivation temperature within $3 \mathrm{~mm}$ of the channel length for all the experimental flow velocities. The assumed inactivation times can thus be considered as close to the real inactivation exposure times that the enzymes experienced.

Control of the reactivation process could be a further advantage with this system, if upon collection at the outlet or by coupling with another microchannel, a solution with denaturing agents is added to the enzyme in order to avoid formation of covalent bonds and thus irreversible enzyme denaturation. The ability to control both inactivation and reactivation, especially in a continuous format is very interesting in terms of application, and could be tested using the presented platform. The continuous enzymatic thermal inactivation system 
could also be used to perform reactions at well-controlled temperatures, allowing introduction or removal of reaction components through the secondary channel. The platform could be further applied to the characterization of enzyme activity at different temperatures, by coupling the system with an online sensor for a reaction product, or even a camera if a colorimetric assay is used, since the system is transparent. By inverting the position of the Peltier elements, in order to achieve temperatures below ambient temperature or even below $273 \mathrm{~K}$, characterization of psychrophilic enzymes could be performed. On the other hand, by changing the Peltier elements to other thermoelectric modules with a wider temperature difference between the cool and the hot side, characterization of thermophilic enzymes could also be attained, greatly extending the applicability of this module.

\section{Acknowledgements:}

The authors thank the funding from the People Programme (Marie Curie Actions, Multi-ITN) of the European Union's Seventh Framework Programme for research, technological development and demonstration under grant agreement no. 608104 (EuroMBR).

\section{References:}

[1] R. Eisenthal, M.E. Peterson, R.M. Daniel, M.J. Danson, The thermal behaviour of enzyme activity: implications for biotechnology, Trends Biotechnol. 24 (2006) 289-292. doi:10.1016/j.tibtech.2006.05.004.

[2] D.C. Demirjian, F. Morís-Varas, C.S. Cassidy, Enzymes from extremophiles, Curr. Opin. Chem. Biol. 5 (2001) 144-151. doi:10.1016/S1367-5931(00)00183-6.

[3] X. Michalet, S. Weiss, M. Jager, Single-molecule fluorescence studies of protein folding and conformational dynamics, Chem. Rev. 106 (2006) 1785-1813. doi:10.1021/cr0404343.

[4] R.M. Murphy, A.M. Tsai, Misbehaving Proteins: Protein (Mis)folding, Aggregation, and Stability, 2006. Springer. doi:10.1007/978-0-387-36063-8.

[5] C. Tsou, Inactivation precedes overall molecular conformation changes during enzyme denaturation, Biochim. Biophys. Acta. 1253 (1995) 151-162. doi:0167-4838/95.

[6] R. Lumry, H. Eyring, Conformation Changes of Proteins, J. Phys. Chem. 58 (1954) 110120. doi:10.1021/j150512a005.

[7] M. Polakovič, P. Vrábel, Analysis of the mechanism and kinetics of thermal inactivation of enzymes: Critical assessment of isothermal inactivation experiments, Process Biochem. 31 (1996) 787-800. doi:10.1016/S0032-9592(96)00026-X.

[8] P. V. Iyer, L. Ananthanarayan, Enzyme stability and stabilization-Aqueous and nonaqueous environment, Process Biochem. 43 (2008) 1019-1032. doi:10.1016/j.procbio.2008.06.004.

[9] T.J. Ahern, A.M. Klibanov, Analysis of Processes Causing Thermal Inactivation of Enzymes, in: D. Glick (Ed.), Methods Biochem. Anal., John Wiley \& Sons, Inc., 1988: pp. 91-127. doi:10.1002/9780470110546.

[10] M. Ahnoff, L.H. Cazares, K. Sköld, Thermal inactivation of enzymes and pathogens in biosamples for MS analysis, Bioanalysis. 7 (2015) 1885-1899. doi:10.4155/bio.15.122.

[11] S.-G. Jeong, O.-D. Baik, D.-H. Kang, Evaluation of radio-frequency heating in 
controlling Salmonella enterica in raw shelled almonds, Int. J. Food Microbiol. 254 (2017) 54-61. doi:10.1016/j.ijfoodmicro.2017.04.007.

[12] H. Jaeger, A. Janositz, D. Knorr, The Maillard reaction and its control during food processing. The potential of emerging technologies, Pathol. Biol. 58 (2010) 207-213. doi:10.1016/j.patbio.2009.09.016.

[13] V. Miralles, A. Huerre, F. Malloggi, M.-C. Jullien, A Review of Heating and Temperature Control in Microfluidic Systems: Techniques and Applications, 2013. doi:10.3390/diagnostics3010033.

[14] T. Yamamoto, T. Fujii, T. Nojima, PDMS-glass hybrid microreactor array with embedded temperature control device. Application to cell-free protein synthesis, Lab Chip. 2 (2002) 197-202. doi:10.1039/B205010B.

[15] M.G. Roper, C.J. Easley, J.P. Landers, Advances in polymerase chain reaction on microfluidic chips, Anal. Chem. 77 (2005) 3887-3893. doi:10.1021/ac050756m.

[16] V.N. Hoang, G. V. Kaigala, A. Atrazhev, L.M. Pilarski, C.J. Backhouse, Strategies for enhancing the speed and integration of microchip genetic amplification, Electrophoresis. 29 (2008) 4684-4694. doi:10.1002/elps.200800351.

[17] G. Wang, H.-P. Ho, Q. Chen, A.K.-L. Yang, H.-C. Kwok, S.-Y. Wu, S.-K. Kong, Y.-W. Kwan, X. Zhang, A lab-in-a-droplet bioassay strategy for centrifugal microfluidics with density difference pumping, power to disc and bidirectional flow control, Lab Chip. 13 (2013) 3698. doi:10.1039/c3lc50545f.

[18] P. Attri, E.H. Choi, Influence of Reactive Oxygen Species on the Enzyme Stability and Activity in the Presence of Ionic Liquids, PLoS One. 8 (2013). doi:10.1371/journal.pone.0075096.

[19] E.A. Oblath, W.H. Henley, J.P. Alarie, J.M. Ramsey, A microfluidic chip integrating DNA extraction and real-time PCR for the detection of bacteria in saliva, Lab Chip. 13 (2013) 1325. doi:10.1039/c3lc40961a.

[20] G. V. Kaigala, J. Jiang, C.J. Backhouse, H.J. Marquez, System design and modeling of a time-varying, nonlinear temperature controller for microfluidics, IEEE Trans. Control Syst. Technol. 18 (2010) 521-530. doi:10.1109/TCST.2009.2015937.

[21] M. Colombo, I. Peretto, Chemistry strategies in early drug discovery: an overview of recent trends, Drug Discov. Today. 13 (2008) 677-684. doi:10.1016/j.drudis.2008.03.007.

[22] J.J. Shah, J. Geist, M. Gaitan, Microwave-induced adjustable nonlinear temperature gradients in microfluidic devices, J. Micromechanics Microengineering. 20 (2010) 105025. doi:10.1088/0960-1317/20/10/105025.

[23] M.S. Boybay, A. Jiao, T. Glawdel, C.L. Ren, Microwave sensing and heating of individual droplets in microfluidic devices, Lab Chip. 13 (2013) 3840-3846. doi:10.1039/c3lc50418b.

[24] B.C. Giordano, J. Ferrance, S. Swedberg, A.F.R. Hühmer, J.P. Landers, Polymerase Chain Reaction in Polymeric Microchips: DNA Amplification in Less Than 240 Seconds, Anal. Biochem. 291 (2001) 124-132. doi:10.1006/abio.2000.4974.

[25] Y. Yu, B. Li, C. a Baker, X. Zhang, M.G. Roper, Quantitative polymerase chain reaction using infrared heating on a microfluidic chip, Anal Chem. 84 (2012) 2825-2829. doi:10.1021/ac203307h.

[26] M. Subramanian, A. Miaskowski, G. Pearce, J. Dobson, A coil system for real-time magnetic fluid hyperthermia microscopy studies, Int. J. Hyperth. 32 (2016) 112-120. doi:10.3109/02656736.2015.1104732.

[27] S. Singh, K.C. Barick, D. Bahadur, Inactivation of bacterial pathogens under magnetic hyperthermia using Fe $3 \mathrm{O} 4$ - ZnO nanocomposite, Powder Technol. 269 (2015) 513519. doi:10.1016/j.powtec.2014.09.032.

[28] C. Haber, Microfluidics in commercial applications; an industry perspective., Lab Chip. 
6 (2006) 1118-1121. doi:10.1039/b610250f.

[29] D. Mark, S. Haeberle, G. Roth, F. von Stetten, R. Zengerle, Microfluidic lab-on-a-chip platforms: requirements, characteristics and applications., Chem. Soc. Rev. 39 (2010) 1153-82. doi:10.1039/b820557b.

[30] N. Hlawatsch, R. Klemm, C. Carstens, T. Brandstëtter, H. Becker, R. Elbracht, C. Gärtner, A lab-on-a-chip system for the development of complex assays using modular microfluidic components, Microfluid. BioMEMS, Med. Microsystems X. 8251 (2012). doi:10.1117/12.910269.

[31] D. Sabourin, P. Skafte-Pedersen, M.J. Søe, M. Hemmingsen, M. Alberti, V. Coman, J. Petersen, J. Emnéus, J.P. Kutter, D. Snakenborg, F. Jørgensen, C. Clausen, K. Holmstrøm, M. Dufva, The MainSTREAM component platform: a holistic approach to microfluidic system design., J. Lab. Autom. 18 (2013) 212-228. doi:10.1177/2211068212461445.

[32] J. Lim, F. Maes, V. Taly, J.-C. Baret, The microfluidic puzzle: chip-oriented rapid prototyping, Lab Chip. 14 (2014) 1669. doi:10.1039/c3lc51399h.

[33] K. Vittayarukskul, A.P. Lee, A truly Lego ${ }^{\circledR}$-like modular microfluidics platform, J. Micromechanics Microengineering. 27 (2017) 35004. doi:10.1088/1361-6439/aa53ed.

[34] D.P.H.M. Heuts, E.W. Van Hellemond, D.B. Janssen, M.W. Fraaije, Discovery, characterization, and kinetic analysis of an alditol oxidase from Streptomyces coelicolor, J. Biol. Chem. 282 (2007) 20283-20291. doi:10.1074/jbc.M610849200.

[35] R.F.B. and I.W. Sizer, A Spectrophotometric Method for Measuring the Breakdown of Hydrogen Peroxide By Catalase, J. Biol. Chem. 195 (1952) 133-140.

[36] H. Lück, Catalase, in: H.-Ui. Bergmeyer (Ed.), Methods Enzym. Anal., 1st ed., Elsevier, 1965: pp. 885-888.

[37] Y.Y. Yan, Recent Advances in Computational Simulation of Macro-, Meso-, and MicroScale Biomimetics Related Fluid Flow Problems, J. Bionic Eng. 4 (2007) 97-107. doi:10.1016/S1672-6529(07)60021-3.

[38] A.B. Thrane, Lars, W. Paul, Bakker, Brameshuber, B. Cazacliu, L. Ferrara, D. Feys, M. Geiker, A. Gram, S.M., Steffen Grünewald, N. Roquet, S.U. NicolasRoussel, Surendra Shah, Nathan Tregger, and J.E.W. Frederick Van Waarde, Computational Fluid Dynamics, in: N. Roussel, A. Gram (Eds.), Simul. Fresh Concr. Flow, Springer, 2014: pp. 25-63. doi:10.1007/978-94-017-8884-7.

[39] D.L. Brown, R. Cortez, M.L. Minion, Accurate Projection Methods for the Incompressible Navier-Stokes Equations, J. Comput. Phys. 168 (2001) 464-499. doi:10.1006/jcph.2001.6715.

[40] G.M. Mala, D. Li, J.D. Dale, Heat transfer and fluid flow in microchannels, Int. J. Heat Mass Transf. 40 (1997) 3079-3088. doi:10.1016/S0017-9310(96)00356-0.

[41] V. V. Mozhaev, K. Martinek, Inactivation and reactivation of proteins (enzymes), Enzyme Microb. Technol. 4 (1982) 299-309. doi:10.1016/0141-0229(82)90050-3.

[42] R. Fernandez-Lafuente, Stabilization of multimeric enzymes: Strategies to prevent subunit dissociation, Enzyme Microb. Technol. 45 (2009) 405-418. doi:10.1016/j.enzmictec.2009.08.009.

[43] M.D. Gouda, S.A. Singh, A.G.A. Rao, M.S. Thakur, N.G. Karanth, Thermal inactivation of glucose oxidase: Mechanism and stabilization using additives, J. Biol. Chem. 278 (2003) 24324-24333. doi:10.1074/jbc.M208711200.

[44] G. Zoldák, A. Zubrik, A. Musatov, M. Stupák, E. Sedlák, Irreversible thermal denaturation of glucose oxidase from Aspergillus niger is the transition to the denatured state with residual structure, J. Biol. Chem. 279 (2004) 47601-47609. doi:10.1074/jbc.M406883200.

[45] I.W. Sizer, Temperature activation and inactivation of the crystalline catalase-hydrogen 
peroxide system, J. Biol. Chem. (1944) 461-473.

[46] H.C. Eyster, Effect of Temperature on Catalase Activity, Ohio J. Sci. 50 (1950) 273-277. http://hdl.handle.net/1811/3787.

[47] M. Bartoszek, M. Kściuczyk, Study of the temperature influence on catalase using spin labelling method, J. Mol. Struct. 744-747 (2005) 733-736. doi:10.1016/j.molstruc.2004.11.080.

[48] I. V Sochava, T. V Belopolskaya, O.I. Smirnova, Dsc Study of Reversible and Irreversible Thermal Denaturation of Concentrated Globular Protein Solutions, Biophys. Chem. 22 (1985) 323-336. http://www.sciencedirect.com/science/article/B6TFB44FDPS6-HC/2/f713d865e32bb76544ee795515fd7aee.

\section{Figure legends}

Figure 1 - Schematics and photograph of the assembled microfluidic platform for thermal inactivation of enzymes, with the different components highlighted. In the photograph emphasized with blue dots the inlet and outlet of the main channel, while in green the inlet and outlet of the secondary channel are signalled.

Figure 2 - Schematics of polycarbonate plate with engraved microfluidic channel (a) where the primary (in blue) and secondary (in green) inlets are highlighted, and schematics of the microfluidic channel used in the CFD simulations (b), where flow direction, position of the microchannel and heating are highlighted.

Figure 3 - Schematics of sampling in the microfluidic thermal inactivation platform.

Figure 4 - Schematics of 4-mL vial designed in SolidWorks with the slice used for CFD simulations shown (a) and simulated slice of $4-\mathrm{mL}$ vial with different parts and heating highlighted (b).

Figure 5 - Results from the CFD simulation of part of the 4-mL vial considering the glass was pre-heated at $353 \mathrm{~K}$ (a), $318 \mathrm{~K}$ (b) and $298 \mathrm{~K}$ (c) for the different residence times used.

Figure 6 - Results from CFD simulation of the simplified geometry of the microchannel considering the bottom of the channel is heated at $353 \mathrm{~K}$ (a), $318 \mathrm{~K}$ (b) and $298 \mathrm{~K}$ (c) and the average linear flow velocity is $0.0018 \mathrm{~m} / \mathrm{s}$.

Figure 7 - Results from CFD simulation of the simplified geometry of the microchannel considering the bottom of the channel is heated at $353 \mathrm{~K}$ for different flow velocities.

Figure 8- Amount of colorimetric product formation by GOx and hydrogen peroxide consumed by Cat, measured in the spectrophotometer immediately after inactivation in the 
ThermoMixer ((a) for GOx and (c) for Cat) and microfluidic platform ((b) for GOx and (d) for Cat)

Figure 9 - Substrate consumed by the static and in flow inactivated enzymes (GOx (a) and Cat (b) after 1 and 2 days. The black line represents the maximum value of glucose (a) consumed by the enzyme solutions inactivated in the microfluidic system. Samples of $20 \mathrm{~s}$ inactivation times were only measured for the higher temperatures ( $328 \mathrm{~K}, 338 \mathrm{~K}$ and $353 \mathrm{~K})$ used in the microfluidic thermal inactivation platform.

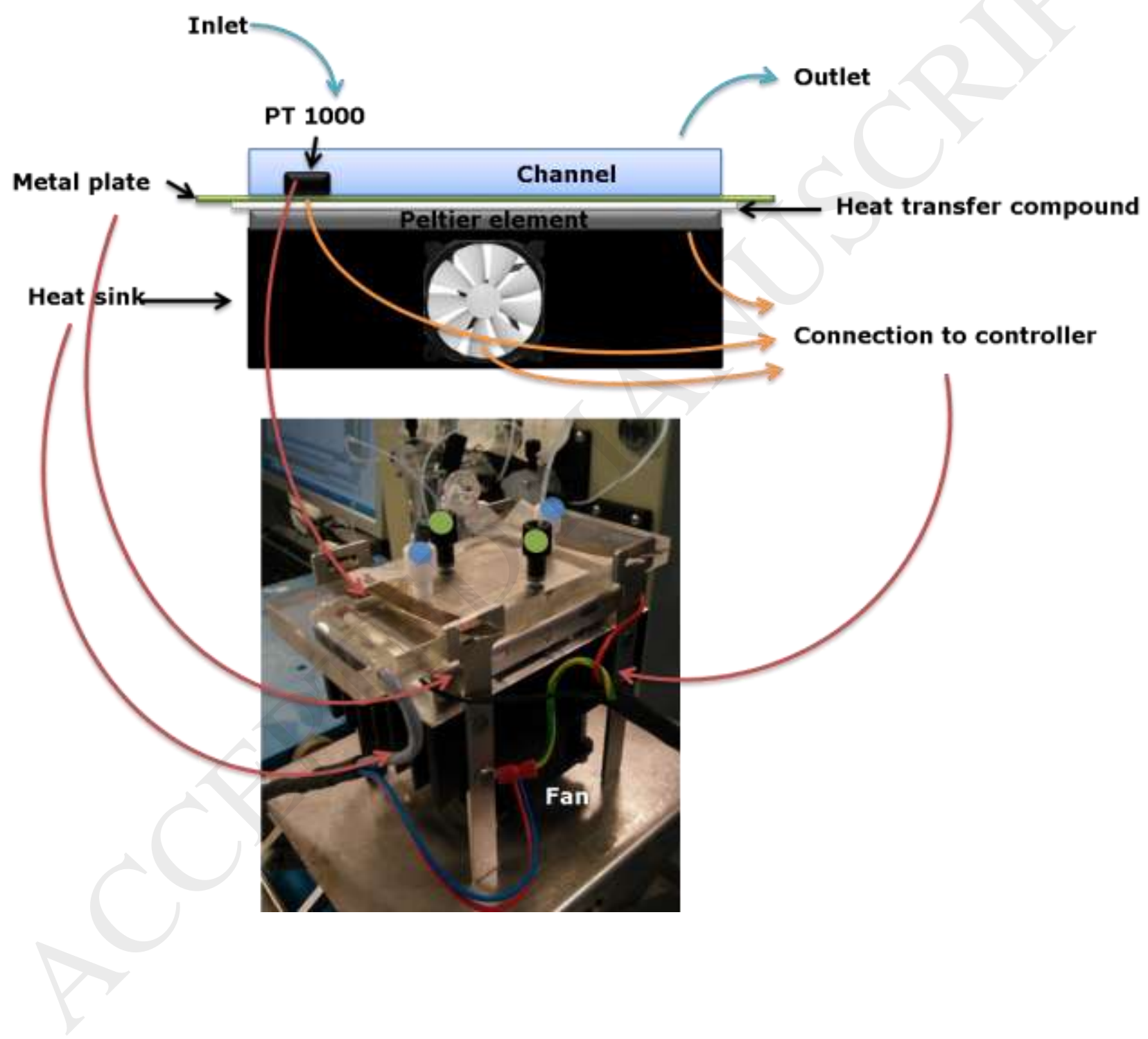




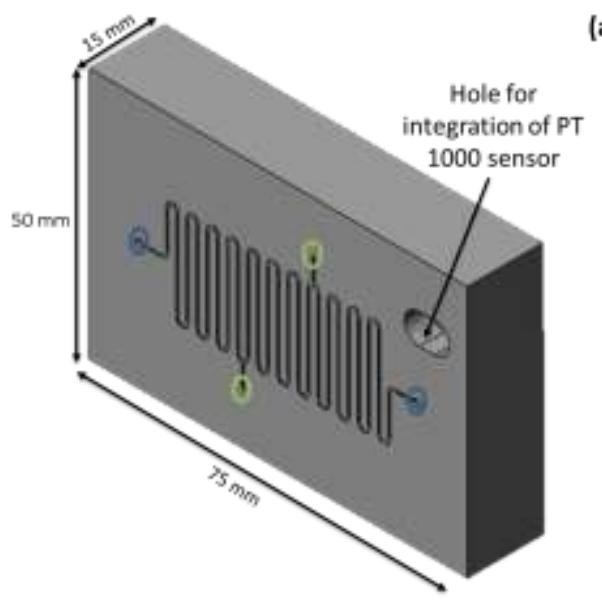

(a)

(b)
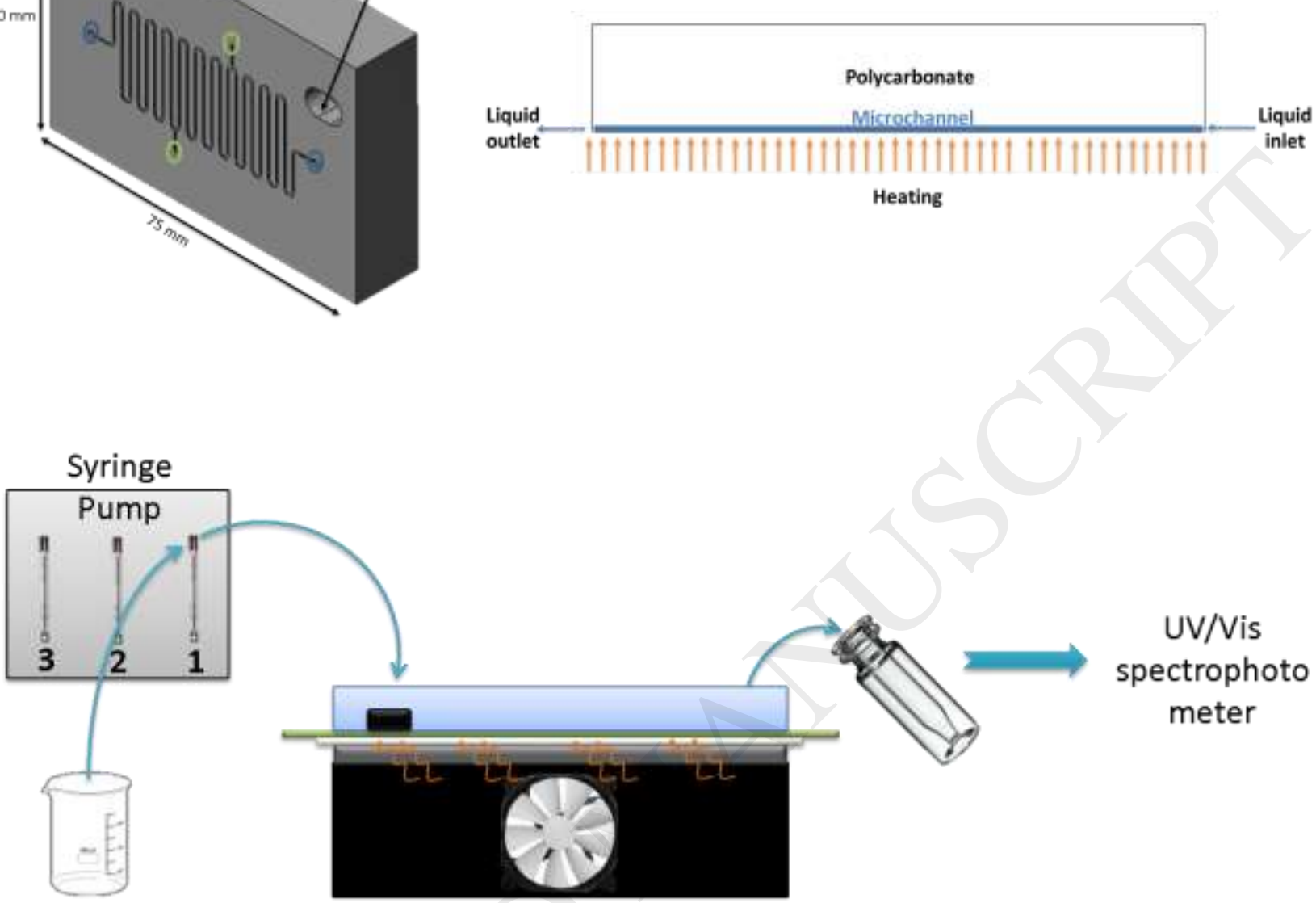

GOx or Cat

solution 
(a)

(b)

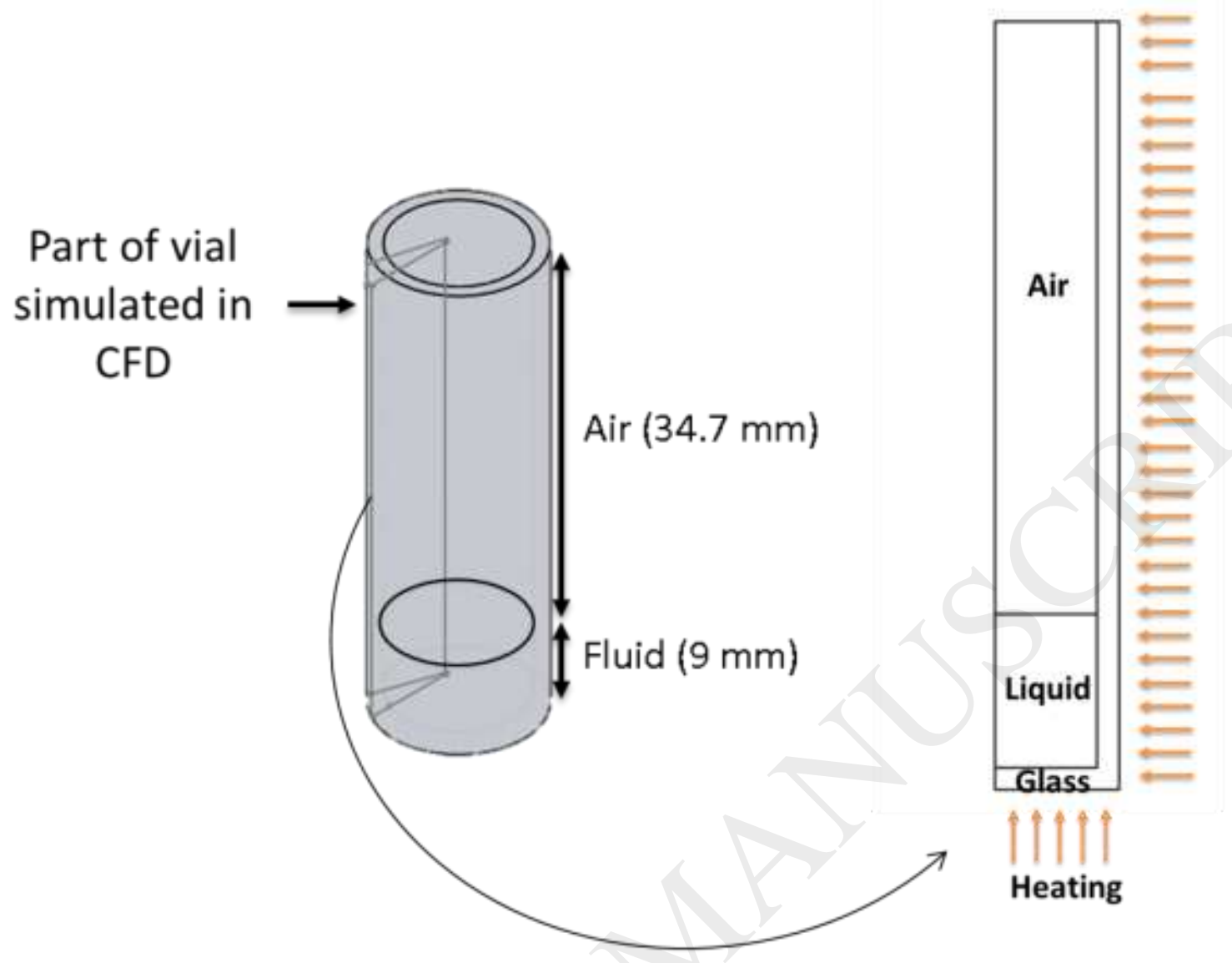




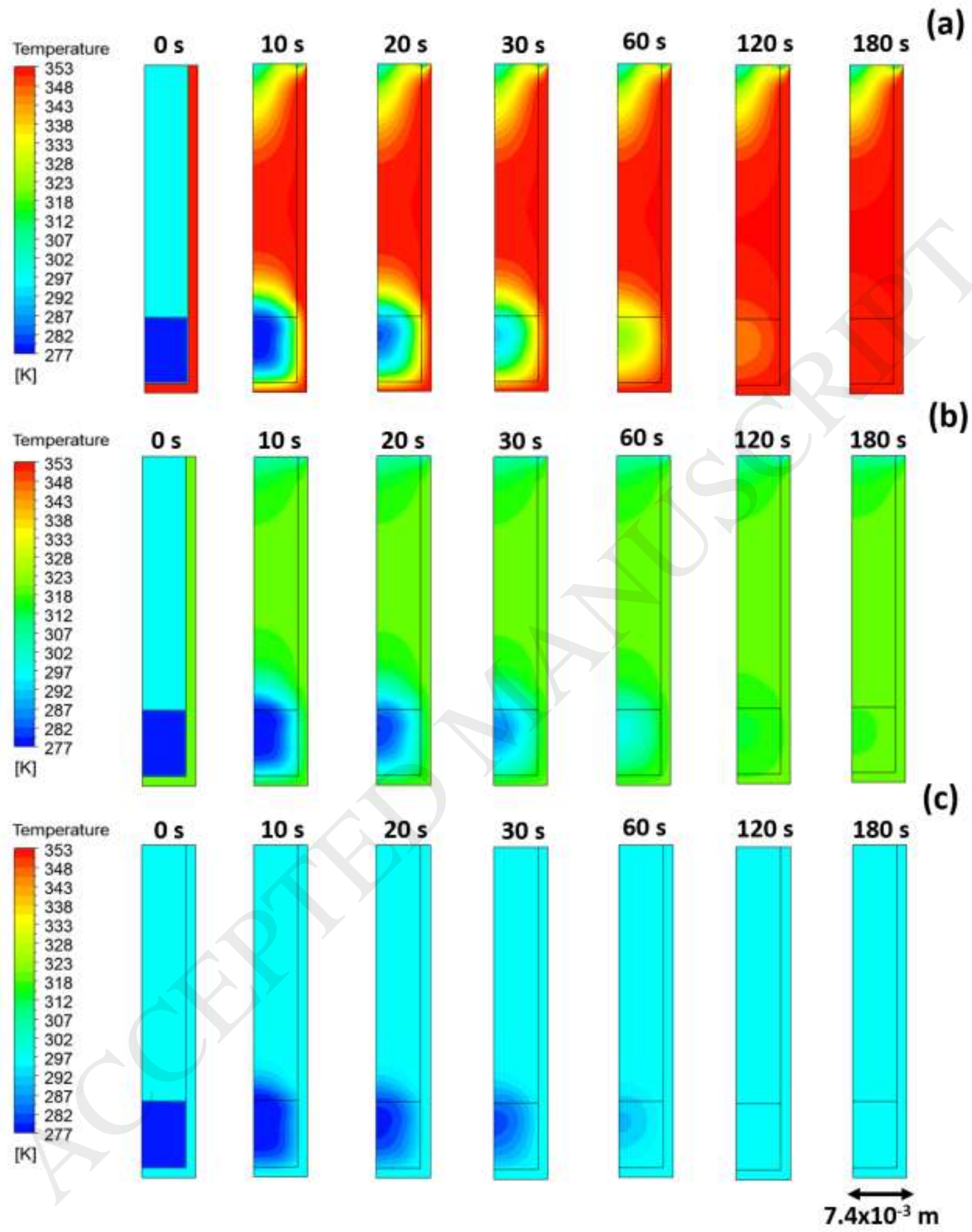




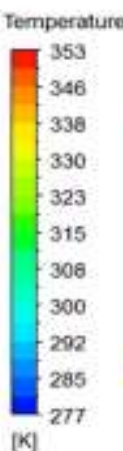

Temperature
$\begin{aligned} & 318 \\ & 314 \\ & 310 \\ & 306 \\ & 302 \\ & 208 \\ & 294 \\ & 289 \\ & 285 \\ & 281 \\ & 277\end{aligned}$

(K)
$0.3 \mathrm{~s}$
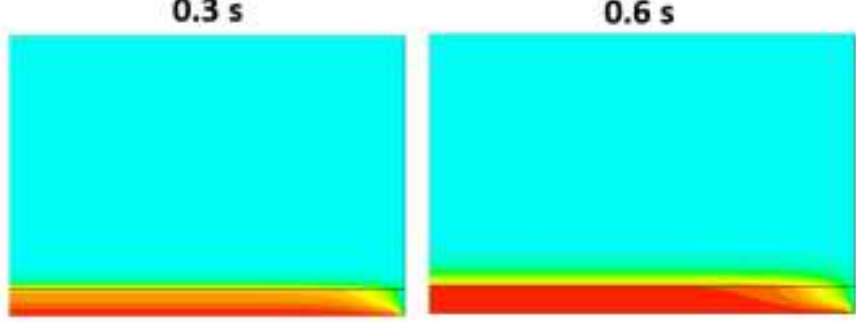

$0.3 \mathrm{~s}$
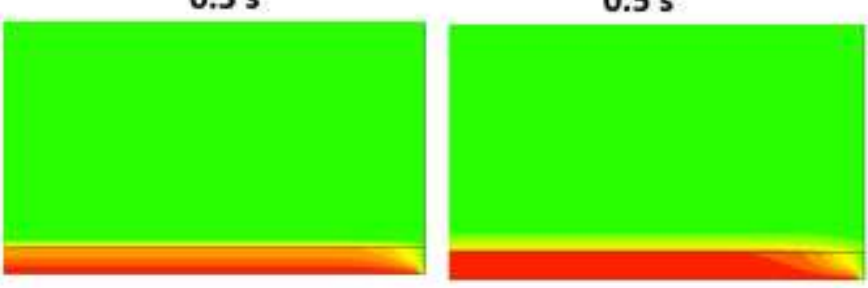

$0.4 \mathrm{~s}$
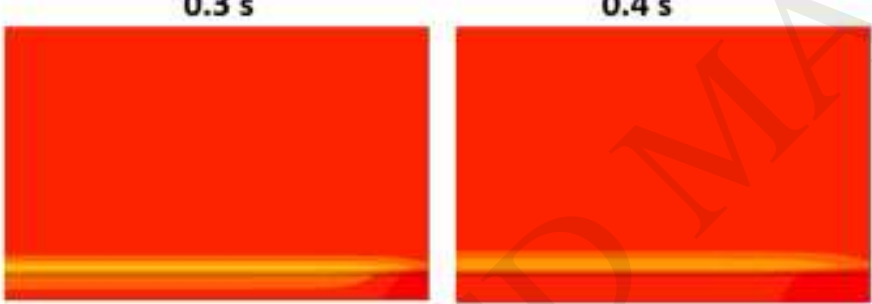

$3600 \mathrm{~s}$

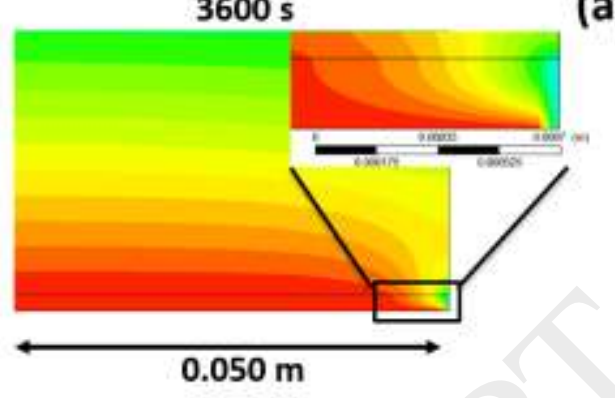

$3600 \mathrm{~s}$

(b)

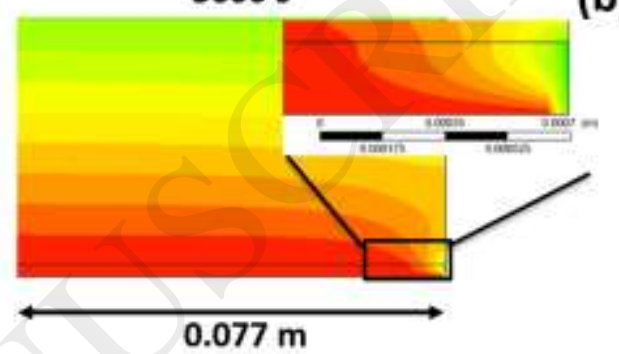

(c)

(a)

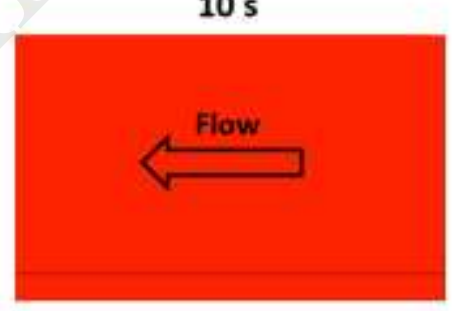




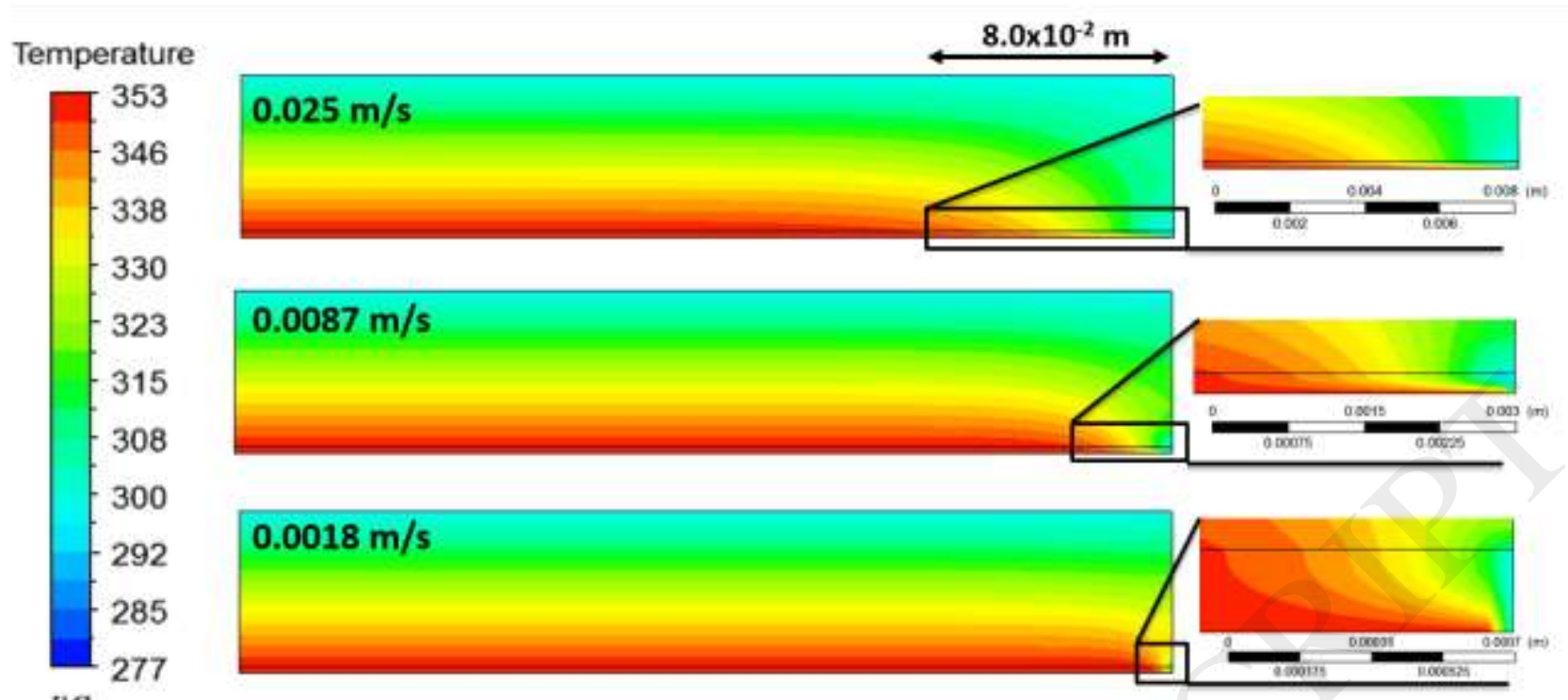

[K]
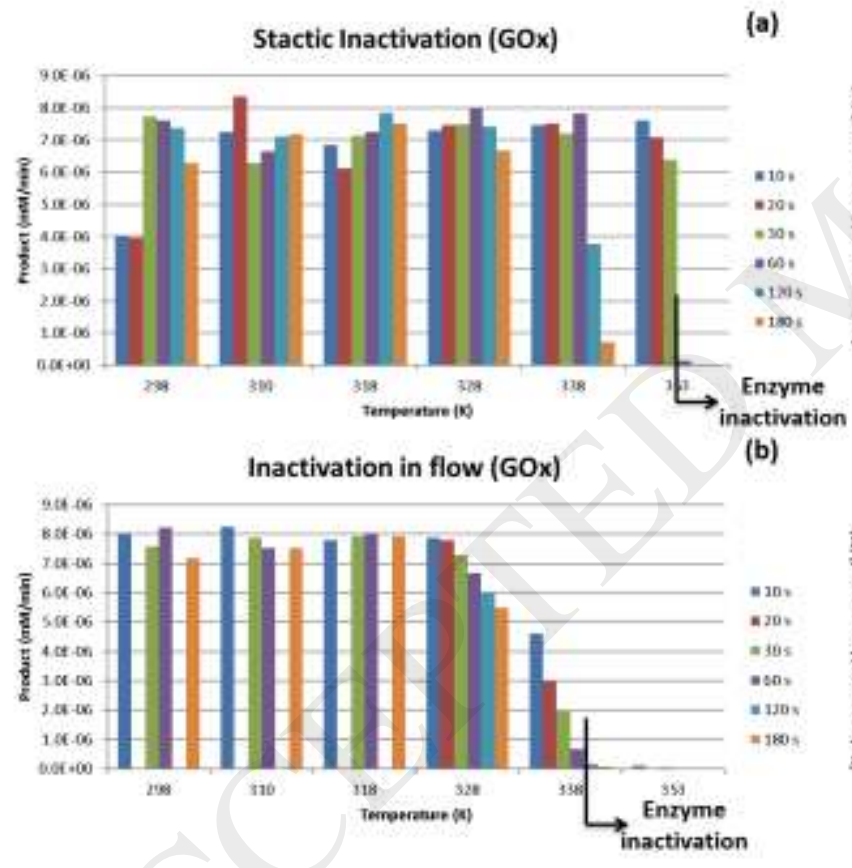

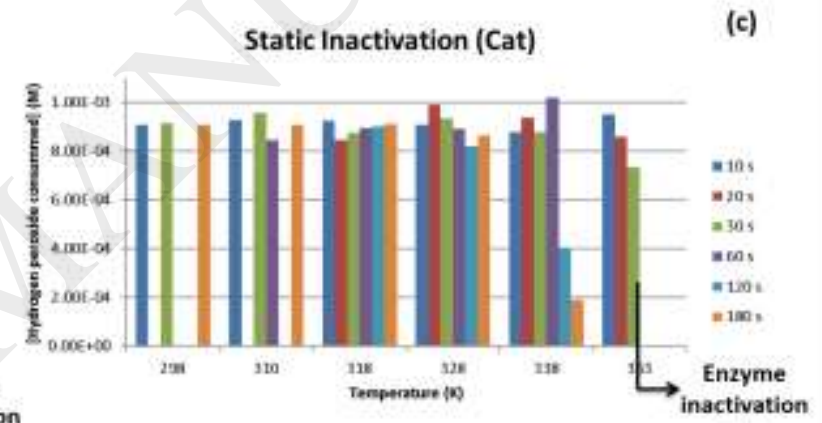

Inactivation in flow (spectrophotometer)

(d)

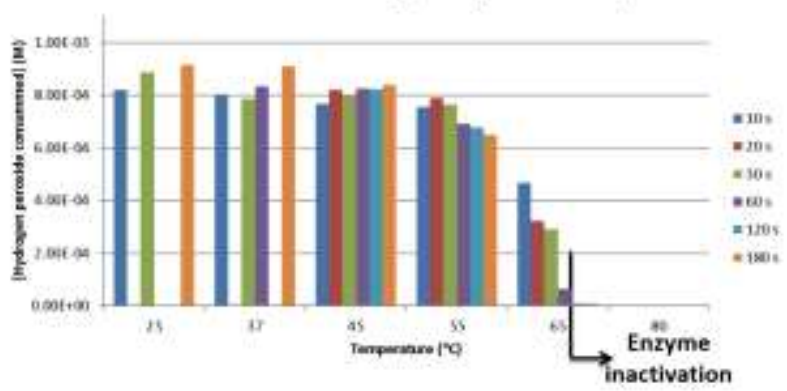




\section{Comparison of deactivation efficiency}

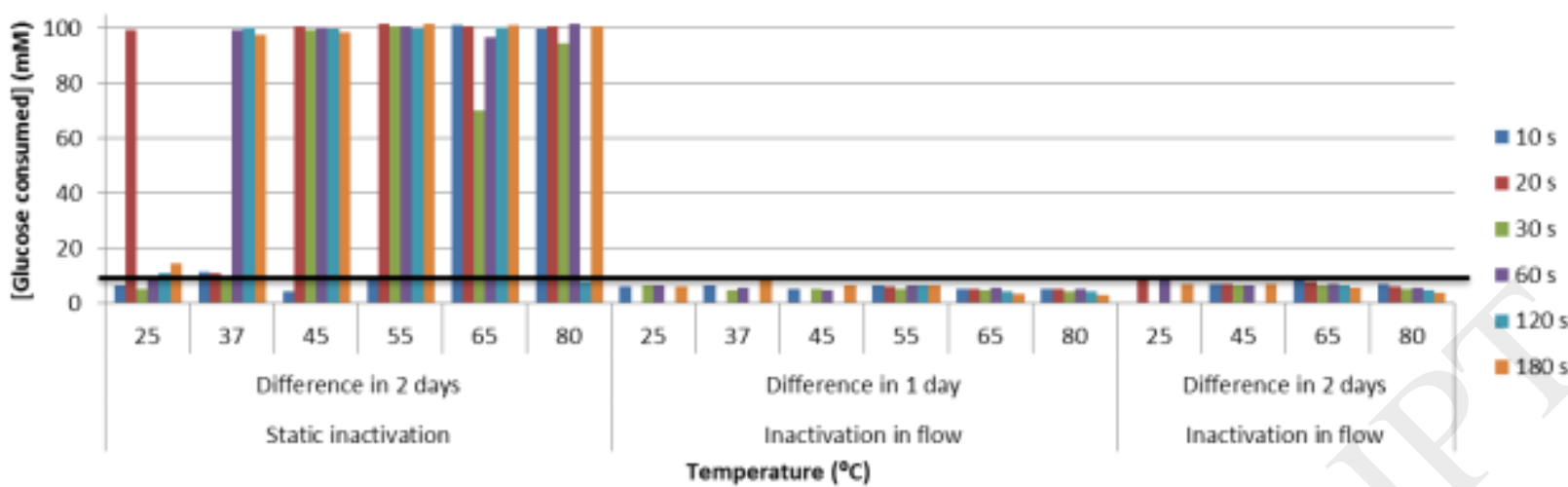

\section{Comparison of deactivation efficiency (Cat)}

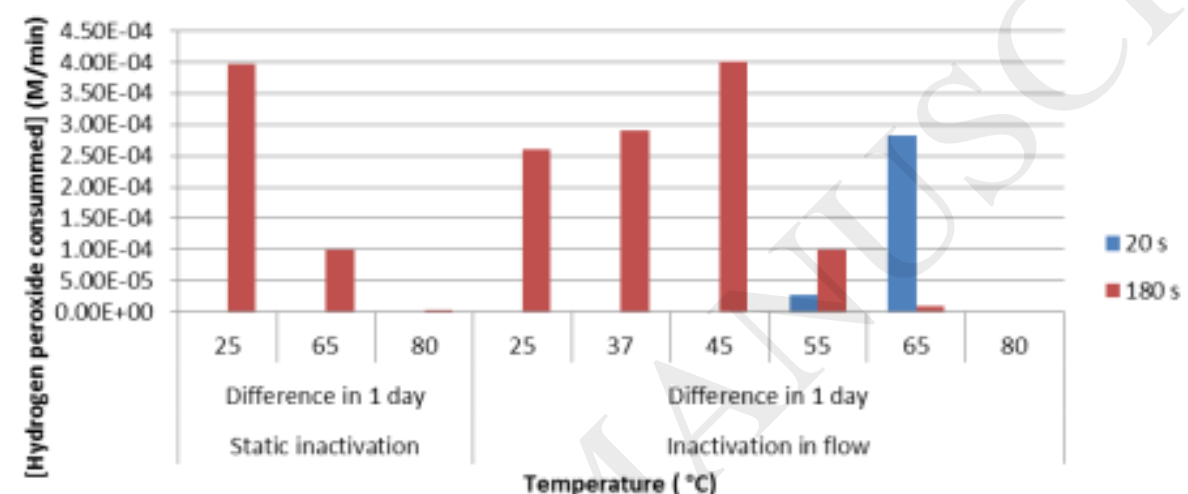

Table 1 - Summary of main thermal properties and applications of several heating strategies at the microscale.

\begin{tabular}{|c|c|c|c|c|}
\hline Heating strategy & $\begin{array}{c}\text { Heating/ } \\
\text { Cooling rate } \\
(\mathrm{K} / \mathrm{s})\end{array}$ & $\begin{array}{l}\text { Temperature } \\
\text { range (K) }\end{array}$ & $\begin{array}{l}\text { Response } \\
\text { time }\end{array}$ & Application \\
\hline (Thin-film) resistors & $5-20$ & $298-383$ & & PCR [38], [22], [23], lab-on-a-disc [24], \\
\hline $\begin{array}{l}\text { Thermoelectric modules } \\
\text { (TEM) }\end{array}$ & $20-100$ & $270-393$ & $1 \mathrm{~s}-3 \mathrm{~min}$ & $\begin{array}{c}\text { PCR [38], [27], [26], thermal } \\
\text { management [39] }\end{array}$ \\
\hline $\begin{array}{l}\text { Microwave (MW) } \\
\text { heating }\end{array}$ & $5-30000$ & $298-368$ & $\mathrm{~ms}-\mathrm{s}$ & $\begin{array}{l}\text { PCR [20], Hydrogel polymerization [31], } \\
\text { Flow chemistry/drug discovery [29] }\end{array}$ \\
\hline Infrared (IR) heating & $10-65$ & $298-368$ & $\mathrm{~ms}-\mathrm{s}$ & $\begin{array}{c}\text { PCR [32], [38], [33], Enzyme inactivation } \\
\text { [37] }\end{array}$ \\
\hline $\begin{array}{l}\text { Radio-frequency (RF) } \\
\text { heating }\end{array}$ & - & $298-373$ & - & MHF [34], inactivation of bacteria [36] \\
\hline
\end{tabular}


Table 2 - Residence times and temperatures used for the characterization of the microfluidic thermal inactivation platform and comparison with the ThermoMixer.

\begin{tabular}{cccc}
\hline Channel & Residence time (s) & Flow velocity $\left(\mathbf{m s}^{-\mathbf{1}}\right)$ & Temperature (K/ $\left.{ }^{\mathbf{0}} \mathbf{C}\right)$ \\
\hline \multirow{2}{*}{ Secondary channel } & 10 & 0.0087 & $298 / 25$ \\
$(\sim 87 \mathrm{~mm})$ & 20 & 0.0043 & $310 / 37$ \\
& 30 & 0.0029 & $318 / 45$ \\
Main channel & 60 & 0.0054 & $328 / 55$ \\
$(\sim 325 \mathrm{~mm})$ & 120 & 0.0027 & $338 / 65$ \\
& 180 & 0.0018 & $353 / 80$ \\
\hline
\end{tabular}

